\title{
Masking mRNA from translation in somatic cells
}

\author{
Mukul Ranjan, Sherrie R. Tafuri, and Alan P. Wolffe \\ Laboratory of Molecular Embryology, National Institute of Child Health and Human Development, National Institutes \\ of Health, Bethesda, Maryland 20892 USA
}

\begin{abstract}
We present evidence for a role for Y-box proteins in both mRNA transcription and translation. We have expressed an oocyte-specific RNA-binding protein (FRGY2) in somatic cells. This protein is normally found together with mRNA in large amounts within the masked maternal mRNA storage particles of Xenopus laevis oocytes. Masked maternal mRNA is believed to be translationally repressed during oogenesis and is stored within ribonucleoprotein storage particles for subsequent use during embryogenesis. Surprisingly, FRGY2 is not only found to direct the accumulation of mRNA from promoters containing binding sites for the protein but also to selectively repress translation of the same mRNA. Thus, the role of FRGY2 in the transcription and storage of maternal mRNA is similar to that of the transcription factor TFIIIA in the transcription and storage of $5 \mathrm{~S}$ rRNA from the oocyte type $5 \mathrm{~S}$ rRNA genes.
\end{abstract}

[Key Words: mRNA transcription; mRNA translation; Y-box proteins; somatic cells; masked maternal mRNA; cold shock domain]

Received May 26, 1993; revised version accepted July 8, 1993.

Many events in early embryogenesis are dependent on the translational regulation of mRNA synthesized during oogenesis (maternal mRNA). The majority of the maternal mRNA that will be utilized during early development is sequestered during oogenesis into storage ribonucleoprotein particles (mRNPs, informosomes) (Spririn 1969; Davidson 1986; Richter 1991). Assembly of these storage mRNPs is believed to prevent the recruitment of mRNA to ribosomes for translation until the correct developmental time; thus, the maternal mRNA is described as being masked from the translational apparatus (Spirin 1966). The molecular mechanisms responsible for masking mRNA and for releasing the template for translation have not been defined.

In Xenopus laevis, two major proteins, mRNP3 and mRNP4, are associated with maternal mRNA in the storage mRNPs of mature oocytes (Darnbrough and Ford 1981). These proteins have been proposed to regulate the translation of mRNA to which they are bound /Crawford and Richter 1987; Sommerville 1990). mRNP3 and mRNP4 are oocyte specific and have been directly implicated in the repression of mRNA translation in the oocyte (Richter and Smith 1983, 1984; Richter 1988). Recently, the deduced amino acid sequences of mRNP3 and mRNP4 have been obtained (Murray et al. 1992). mRNP4 is identical to a previously characterized Xenopus Y-box factor FRGY2, and mRNP3 has $85 \%$ sequence identity to FRGY2 (Tafuri and Wolffe 1990; Wolffe et al. 1992).

The Y-box proteins are highly conserved through evolution and have significant identity $(55 \%)$ in their DNA- binding domain to prokaryotic cold shock proteins (Goldstein et al. 1990; Av-Gay et al. 1992; Tafuri and Wolffe 1992). Both eukaryotic and prokaryotic proteins interact with similar DNA sequences (ATTGG, Didier et al. 1988; Tafuri and Wolffe 1990, 1992; La Teana et al. 1991; Jones et al. 1992). The eukaryotic proteins will also interact with single-stranded nucleic acid (Kolluri et al. 1992, Wolffe et al. 1992), which may reflect their potential for interaction with mRNA. Previously, we have characterized the expression of two Xenopus Y-box protein genes, FRGY2 and FRGY1. FRGY2 (mRNP4) mRNA is found to be expressed only in germ cells, whereas FRGY1 mRNA accumulates in all tissues examined. FRGY2 protein appears very early in oogenesis, accumulates to high levels in stage-I oocytes, and declines as development proceeds until the protein has disappeared from somatic cells (Wolffe et al. 1992). In contrast, FRGY1 protein is undetectable in oocytes. Both FRGY1 and FRGY2 were found to stimulate transcription from promoters containing Y-box elements (CTGATTGGCCAA / in an in vitro transcription extract prepared from Xenopus eggs (Tafuri and Wolffe 1990, 1992; Toyoda and Wolffe 1992). Thus, both the eukaryotic and prokaryotic Y-box proteins are implicated in facilitating transcription (Tafuri and Wolffe 1990; La Teana et al. 1991; Jones et al. 1992).

We wished to explore the potential dual role of the oocyte-specific Y-box protein FRGY2 (mRNP4) in both activating transcription and in repressing translation in vivo. Through expression of the FRGY2 protein in somatic cells, we find evidence of a role for FRGY2 in both 
the accumulation and utilization of mRNA synthesized by specific promoters. The role of the oocyte-specific FRGY2 protein in maternal mRNA transcription and storage has many similarities to that of TFIIIA in the transcription and storage of oocyte-type 5S rRNA (Pelham and Brown 1980; Wolffe and Brown 1988).

\section{Results}

Expression of FRGY2 in X. laevis somatic cells

Our first experiments sought to optimize expression of FRGY2 in X. laevis somatic A6 cells. The entire FRGY2 cDNA (Tafuri and Wolffe 1990) was fused to the immediate early promoter of the human cytomegalovirus (CMV; Ghazal et al. 1988). This promoter is highly active in A6 cells. Transfection of increasing amounts of the CMV promoter construct driving expression of the FRGY2 cDNA (CMV.Y2) leads to a progressive increase in the amount of FRGY2 protein synthesized up to a maximal level at $4 \mu \mathrm{g}$ of CMV.Y2 (Fig. 1A). Maximal accumulation of FRGY2 following transfection occurs after $48 \mathrm{hr}$ (Fig. 1A), although the protein is detected after only $15 \mathrm{hr}$. We then examined the localization of FRGY1 and FRGY2 proteins in transfected cells. The endogenous FRGY1 protein has a predominantly nuclear localization, whereas the transfected FRGY2 protein has predominantly cytoplasmic staining after $48 \mathrm{hr}$ of transfection (Fig. 1B). The predominant cytoplasmic localization of FRGY2 is consistent with its accumulation in oocyte cytoplasm (Darnbrough and Ford 1981; Murray et al. 1992). The differential accumulation of FRGYl and FRGY2 proteins in nuclear or cytoplasmic compartments suggests that these proteins have different primary functions within the cell.

\section{FRGY2 accumulation correlates directly} with the accumulation of CAT mRNA from Y-boxcontaining promoters

We then examined whether the expression of FRGY2 would influence transcription from a Y-box-containing promoter. Two promoters have been investigated extensively in Xenopus oocytes, the Xenopus $h s p 70$ promoter (Bienz 1984) and the herpes simplex virus thymidine kinase promoter (HSV tk; McKnight and Kingsbury 1982). Both of these promoters contain $\mathrm{Y}$ boxes that are essential for high levels of transcript accumulation (Bienz 1986; Graves et al. 1986). In Xenopus egg extracts, Y-box factors can stimulate transcript accumulation from the hsp70 promoter (Tafuri and Wolffe 1990, 1992). We found that cotransfection of increasing amounts of the CMV.Y2 expression vector with a fixed amount of the Xenopus $h s p 70$ promoter fused to the bacterial chloramphenicol acetyltranferase (CAT) gene leads to an increase in the amount of CAT mRNA accumulating in A6 cells (Fig. 2A, lanes 1-4). This increase is dependent on the presence of intact Y-box sequence elements in the promoter, as mutation of these sites prevented the response

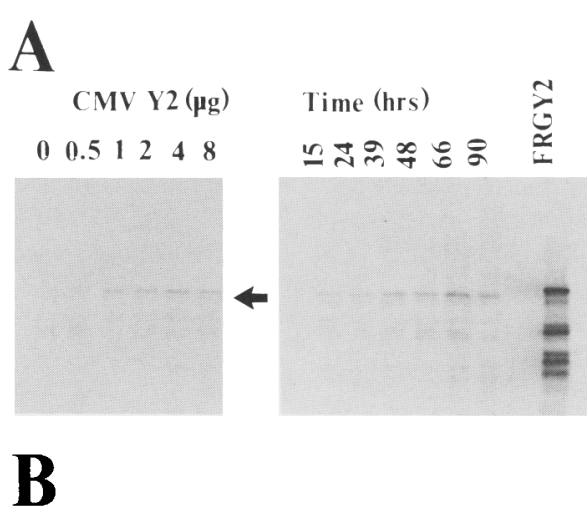

FRG Y2
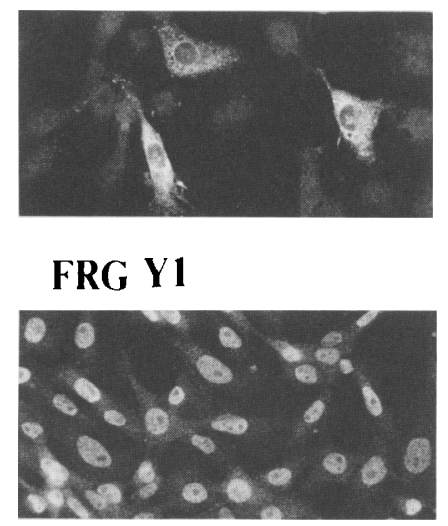

Figure 1. Expression of FRGY2 in somatic cells. (A) Western blot showing a dose response of CMV Y2 in A6 cells. Extracts from cells transfected with increasing amounts of CMV Y2 10-8 $\mu \mathrm{g} / 25-\mathrm{cm}^{2}$ flask). (Right) The time course of FRGY2 induction. A6 cells transfected with $2 \mu \mathrm{g}$ of CMV Y2 were harvested at the indicated times after addition of serum. FRGY2 shows a lane containing bacterially expressed FRGY2 protein; bands below the intact protein are degradation products. $(B)($ Top $)$ A6 cells transfected with $2 \mu \mathrm{g}$ of CMV Y2 and stained with antibodies to FRG Y2; (bottom) untransfected cells stained with antibodies to FRG Y1.

(Fig. 2A, lanes 5-8). In the absence of the Y-box sequence elements, the Xenopus hsp 70 promoter is fairly active in somatic cells in the absence of heat shock. However, in other studies we have been able to induce expression substantially over this basal level through heat shock (M. Ranjan and A.P. Wolffe, unpubl.). We repeated this experiment with the HSV tk promoter, which also contains a Y box (Graves et al. 1986). Once again, accumulation of the FRGY2 protein in A6 cells correlates with an increased accumulation of CAT mRNA derived from the HSV tk promoter-containing construct (Fig. 2B, lanes 1-4). The increase in CAT mRNA levels is dependent on the presence of a $\mathrm{Y}$ box (Fig. 2B, lanes 5-8). We conclude that as observed in vitro (Tafuri and Wolffe 1990, 1992), the FRGY2 protein facilitates transcript accumulation from a Y-box-containing promoter (see also Figs. 7 and 9, below). 


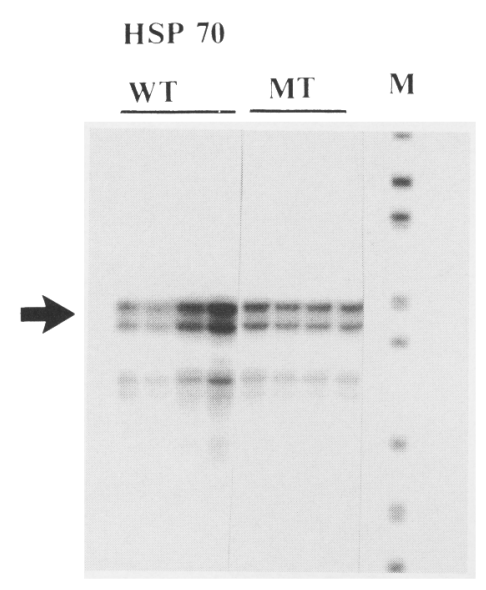

12345678

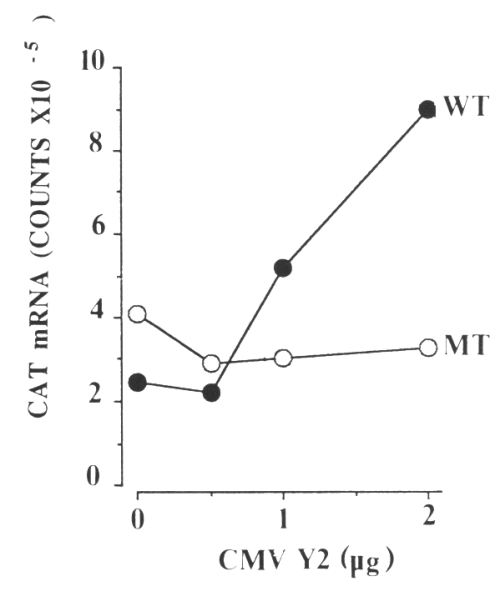

B

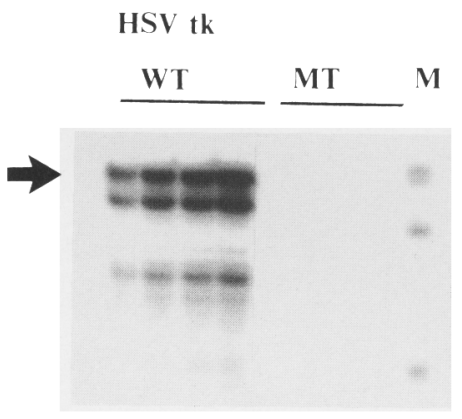

12345678

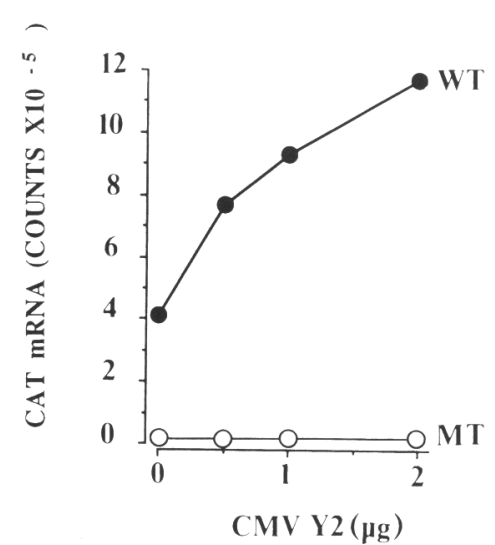

Figure 2. Transcriptional activation by FRGY2 of the $h s p 70$ promoter and HSV tk promoter-driven CAT expression. $|A|(L e f t)$ RNA from cells cotransfected with $1 \mu \mathrm{g}$ of HSPCAT (lanes 1-4) or Y-box mutant HSP-CAT (lanes 5-8) and increasing amounts of CMV $\mathrm{Y} 2 \mid 0,0.5,1$, and $2 \mu \mathrm{g}$ in lanes $1-4$ and 5-8, respectively) analyzed by $\mathrm{RNase}$ protection. Twenty micrograms of total RNA was hybridized to a riboprobe complementary to CAT mRNA, which produces a 117-bp protected fragment (indicated by the horizontal arrow). (M) Markers (pBR322 digested with MspI). (Right) Quantitation of $A$ using a Molecular Dynamics PhosphorImager. (O) Lanes 1-4 (HSP-CAT, WT); (O) lanes 5-8 (Y-box mutant HSP-CAT, MT). (B) (Left) RNA from cells cotransfected with $1 \mu \mathrm{g}$ HSV tk and increasing amounts of CMV Y2 $(0,0.5,1$, and $2 \mu \mathrm{g})$ analyzed by RNase protection. Twenty micrograms of total RNA was hybridized to riboprobe complementary to CAT mRNA, which produces a $117 \cdot \mathrm{bp}$ protected fragment (indicated by the horizontal arrow). (M) Markers (pBR322 digested with MspI). (Right) Quantitation of RNase protection in A. (O) Lanes 1-4 (HSV tK, WT); (O) lanes 5-8 (Y-box mutant HSV tK MT).
FRGY2 accumulation correlates directly with the repression of translation of CAT $M R N A$

Surprisingly, we find that in spite of the increase in CAT mRNA synthesized from the Y-box-containing promoters in response to increased levels of the FRGY2 protein (Fig. 2), the translation of this CAT mRNA is severely reduced (Fig. 3A). Transfection of CMV.Y2 $(2 \mu \mathrm{g})$ in the presence of the Xenopus hsp 70 promoter or the HSV tk promoter increases the amount of CAT mRNA in the cell three- to fivefold (Fig. 2), while at the same time the activity of CAT protein synthesized by that mRNA declines more than fourfold (Fig. 3, left-hand panels). Thus, the translational efficiency of CAT mRNA in A6 cells decreases 16- to 20-fold in the presence of maximal amounts of the FRGY2 protein (Fig. 3, right-hand panels). It should be noted, however, that the CAT mRNA derived from the mutant Xenopus hsp 70 promoter also declines in translation efficiency toward a basal level as the FRGY2 protein accumulates. In other experiments we have found that the accumulation of FRGY2 will inhibit translation of CAT mRNA or of $\beta$-galactosidase mRNA whose synthesis is directed by the CMV or SV40 early promoters. Thus, there is no evidence for a selective repression of translation mediated by the FRGY2 protein (see also Figs. 7 and 9, below). We wished to examine whether the translation of all cellular mRNAs would be similarly repressed by accumulation of the FRGY2 protein. However the low level $(1-5 \%)$ of transfection of Xenopus A6 cells with the FRGY2 expression vector prevented our directly addressing this issue experimentally. Nevertheless, consistent with such a general repression of translation, we have not observed cells that are positively stained for FRGY2 protein entering into mitosis; thus, expression of FRGY2 protein may prevent cell cycle progression (not shown). We conclude that while the accumulation of the oocyte-specific Y-box protein in Xenopus somatic cells leads to a concomitant accumulation of CAT mRNA synthesized from a Y-boxcontaining promoter, there is a marked decline in the 

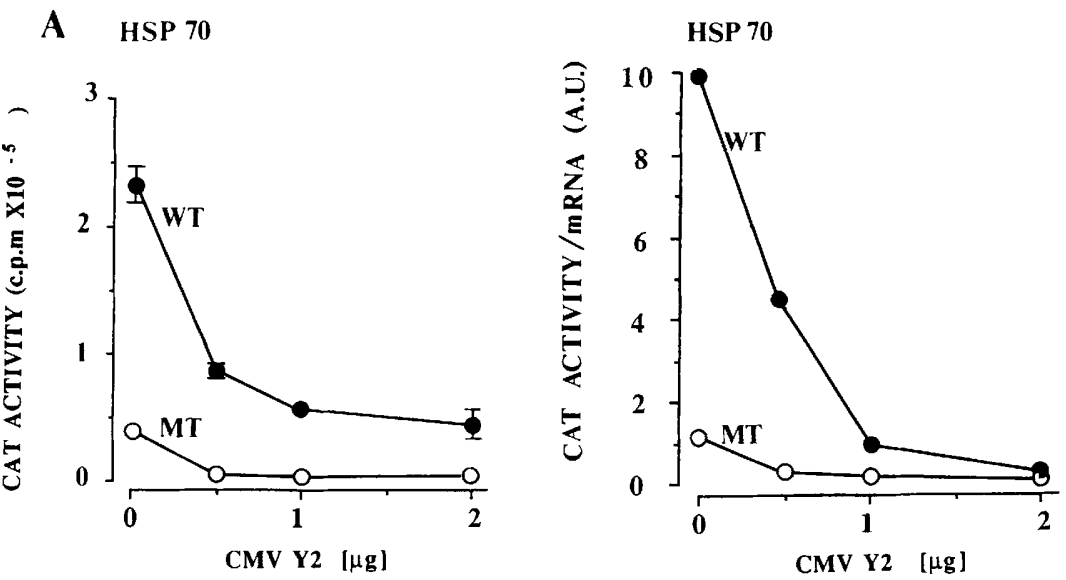

Figure 3. Translational repression by FRGY2 of CAT mRNA expressed from the $h s p 70$ and HSV tK promoters. $(A)($ Left $)$ CAT activity from cells cotransfected with $1 \mu \mathrm{g}$ of HSP-CAT 10 , WT) or Y-box mutant HSP-CAT $(O, M T)$ and increasing amounts of CMV Y2 $(0,0.5,1$, and 2 $\mu \mathrm{g}$ ). (Right) Because the results shown in Fig. $2 \mathrm{~A}$ are derived from the same batch of transfected cells, the CAT activity is expressed as a function of CAT mRNA in arbitrary units (A.U.). (B) (Left) CAT activity from cells contransfected with $1 \mu \mathrm{g}$ of $\mathrm{HSV}$ tK $(0, \mathrm{WT})$ or Y-box mutant HSP-CAT (O, MT) and increasing amounts of CMV Y2 $[0,0.5,1$, and $2 \mu \mathrm{g})$. (Right) Because the results shown in Fig. $2 \mathrm{~B}$ are derived from the same batch of transfected cells, the CAT activity is expressed as a function of CAT mRNA in arbitrary units (A.U.).
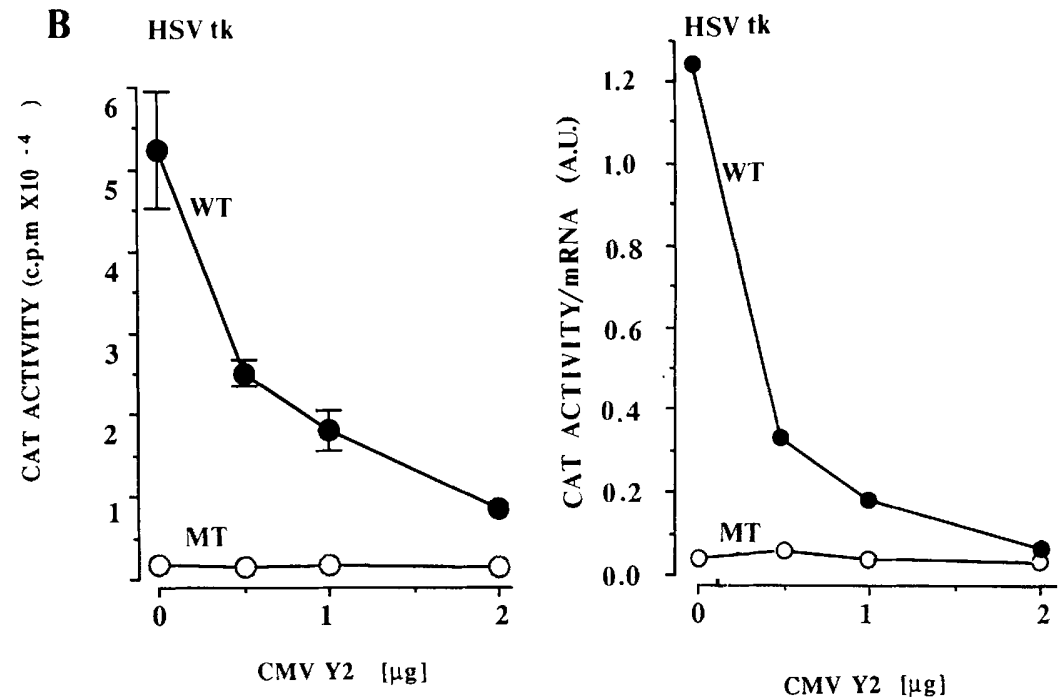

translational efficiency of the mRNA synthesized in these cells.

We then considered the possible molecular mechanisms that might explain the increased accumulation of CAT mRNA and its decreased translation in response to FRGY2 accumulation. Transfection of increasing amounts of the FRGY2 expression vector (CMV.Y2) into Xenopus A6 cells leads to the accumulation both of progressively more mRNA encoding FRGY2 (data not shown) and more FRGY2 protein (Fig. 1A); the accumulation of FRGY2 reaches a maximum, however, between 4 and $8 \mu \mathrm{g}$ of CMV.Y2 per $10^{6}$ cells. Therefore, the introduction of $<4 \mu \mathrm{g}$ of the FRGY2 expression vector itself is not inhibitory to transcription or translation within A6 cells. Likewise, the accumulation of FRGY2 is not inhibitory to the transcription of various promoters, with or without $\mathrm{Y}$ boxes in A6 cells (Fig. 2 and data not shown). However, FRGY2 accumulation also leads to translational inhibition (Fig. 3). We examined whether this effect was specific to FRGY2 by cotransfecting the Xenopus hsp70 promoter driving expression of CAT, with the same CMV vector driving expression of the interleukin-2 receptor (IL-2R) into A6 cells (see also Lauret and Baserga 1988). Although high levels of IL-2R expression lead to some decline in the translation of CAT mRNA, FRGY2 accumulation leads to much more greater decline in CAT activity (Fig. 4). Because FRGY2 also directs accumulation of CAT mRNA (Fig. 2), and IL-2R has no effect on CAT mRNA levels /data not shown), this repression of translation by FRGY2 is even more significant. We conclude that the repression of translation by FRGY2 is specific to expression of this protein.

\section{FRGY2 associates with CAT mRNA but does not prevent its degradation}

We then investigated whether the FRGY2 protein might be associated directly with the CAT mRNA in the cell under conditions of maximal translational repression. The accumulation of FRGY2 protein in the cytoplasm (Fig. 1B) would be consistent with such a mechanism of translational repression (see also Richter and Smith 1984). Maternal mRNA bound to FRGY2 (mRNP4) and mRNP3 reconstitute mRNPs with a characteristic mo- 


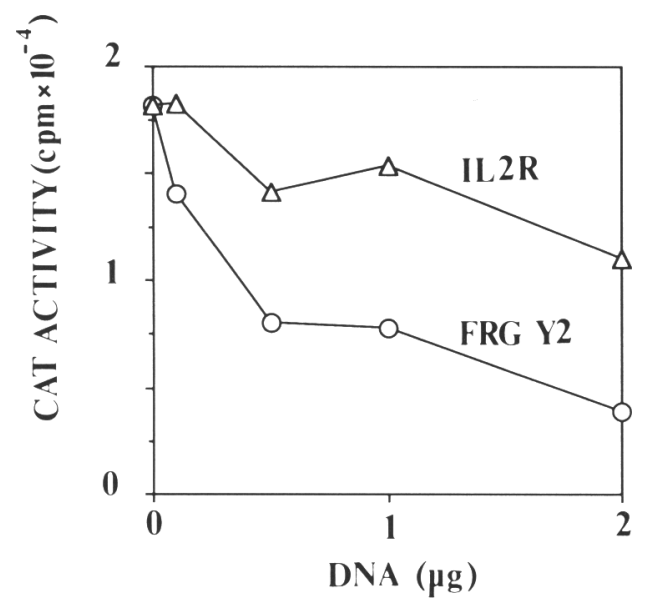

Figure 4. Translational repression specific to FRGY2 expression. CAT activity in cells cotransfected with $1 \mu \mathrm{g}$ of HSP-CAT and increasing amounts $(0,0.5,1$, and $2 \mu \mathrm{g})$ of either CMV.Y2 expressing FRGY2 $(O)$ or CMV.IL2R expressing Il-2R $(\Delta)$.

bility on sucrose or Nycodenz gradients (Sommerville 1990; S.R. Tafuri and A.P. Wolffe, in prep.). Therefore, we resolved ribonucleoprotein complexes formed in cells expressing FRGY2 (such that transcription is maximally stimulated and translation is maximally repressed) on Nycodenz gradients and examined whether the CAT mRNA cofractionated with the FRGY2 protein. The gradient profiles show that the CAT mRNA and FRGY2 are in the same fractions (Fig. 5A,B). Similar reconstitutions of mRNPs with mRNA and Y-box proteins have been described previously (Tafuri et al. 1993). The mRNA and FRGY2 can also be cofractionated on oligo(dT)-cellulose columns, and substitution of bromouridine into the mRNA allows efficient UV cross-linking of FRGY2 to the mRNA (S.R. Tafuri and A.P. Wolffe, in prep.; see Tafuri et al. 1993). However, some cofractionation of FRGY2 with ribosomes also occurs (Fig. 5B,C), perhaps reflecting association of FRGY2 with CAT mRNA that has already been recruited to ribosomes (see also Sommerville 1990). Some FRGY2 and the majority of the protein remain at the top of the gradient /fractions 1-4, not shown). We suggest that the association of CAT mRNA with FRGY2 in somatic cells is important for preventing translation. The presence of FRGY2 may not, however, prevent association of CAT mRNA with ribosomes. However, it should be noted that very little CAT mRNA is ever found associated with ribosomes or polysomes in these cells even under conditions of maximal CAT activity. Other mRNAs, such as those encoding

B

FRG Y2

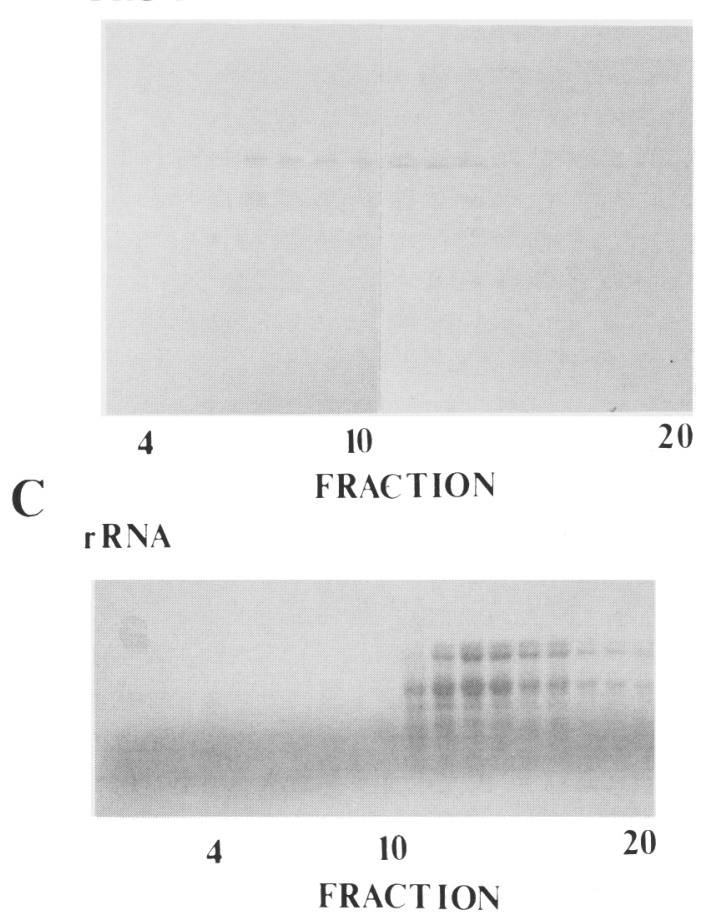

Figure 5. CAT mRNA and FRGY2 cofractionate on Nycodenz gradients that resolve RNPs from transfected Xenopus A6 cells. (A) RNPs within soluble extracts of cells transfected either with $2 \mu \mathrm{g}$ of HSP-CAT ( $\square$ ) or $2 \mu \mathrm{g}$ of HSP-CAT plus $2 \mu \mathrm{g}$ of CMV Y2 (घ) were resolved on Nycodenz gradients into the 20 fractions. These were then analyzed for CAT mRNA by RNase protection, followed by quantitation on a Molecular Dynamics PhosphorImager. $(B)$ The fractions from cells transfected with $2 \mu \mathrm{g}$ of HSP-CAT $+2 \mu \mathrm{g}$ of CMV Y2 were also analyzed by immunoblotting with antibodies against FRGY2 to determine the location of expressed FRGY2. (C) The fractions from cells transfected with $2 \mu \mathrm{g}$ of HSP-CAT $+2 \mu \mathrm{g}$ of CMV Y2 were also analyzed for rRNA by denaturing agarose gel electrophoresis. 
FRGYl or histone $\mathrm{Hl}$, are present almost exclusively in the ribosomal fraction in somatic cells (not shown).

The accumulation of FRGY2 in the cytoplasm of Xenopus somatic cells (Fig. 1B) and the association of the protein with CAT mRNA are consistent with a role for FRGY2 in translational repression. This creates a paradoxical situation because FRGY2 also stimulates transcription, which would demand a nuclear localization. However, a precedent for this observation exists because the Xenopus transcription factor TFIIIA accumulates in the cytoplasm (in association with 5S rRNA) yet also stimulates transcription of the Xenopus $5 \mathrm{~S}$ rRNA genes (Engelke et al. 1980; Mattaj et al. 1983). Therefore, it is possible that a small amount of FRGY2 enters the nucleus to activate transcription but, compared with the large amount in the cytoplasm, escapes immunofluorescent detection. This is the case with TFIIIA in oocytes (Engelke et al. 1980; Mattaj et al. 1983). Alternatively the accumulation of FRGY2 in the cytoplasm might facilitate the transcriptional activity of FRGY1, possibly by removing nonfunctional binding sites for FRGY1 in the cytoplasm. To clarify the potential role of the FRGY2 protein in transcription in vivo, as seen in vitro (Tafuri and Wolffe 1990, 1992), we then investigated whether the accumulation of CAT mRNA in response to FRGY2 is the result of a change in CAT mRNA transcription, nuclear export, or stability. Preliminary experiments indicated that the relatively low transfection efficiency of the A6 cells $(1-5 \%)$ precluded the examination of CAT mRNA transcription by nuclear run-on assays. Therefore, we examined the relative steady-state levels of CAT mRNA in nuclei and whole cells in the presence or absence of FRGY2. The hsp70 promoter is cotransfected with the FRGY2 expression vector into somatic cells such that CAT mRNA accumulation is stimulated. CAT mRNA is then isolated either from the cell nuclei or from the whole cells. FRGY2 accumulation causes a doubling of the amount of nuclear CAT mRNA and a $30 \%$ increase in total CAT mRNA (Fig. 6A). We suggest that FRGY2 plays a direct role in increasing the level of CAT mRNA in the nucleus, consistent with either an increased transcriptional activity of the $h s p 70$ promoter or a decrease in nuclear export.

Because FRGY2 accumulates in the cytoplasm (Fig. 1B), one attractive mechanism for explaining the increase in CAT mRNA levels would be a stabilization of CAT mRNA. This would be consistent with the observed translational repression (Figs. 3 and 4) and a second potential role of these proteins in vivo, which is to stably mask the maternal mRNA from nucleases (Darnbrough and Ford 1981). We cotransfected the FRGY2 expression vector and the $h s p 70$ promoter into somatic cells and allowed FRGY2 and CAT mRNA to accumulate. We then inhibited further transcription through the addition of actinomycin D and followed the decay of CAT mRNA in the presence or absence of FRGY2 (Fig. 6B). No significant difference in the half-life of CAT mRNA $(\sim 2 \mathrm{hr})$ was observed. Therefore, FRGY2 does not stabilize CAT mRNA in Xenopus somatic cells.

Our results strongly suggest that the increased accu-
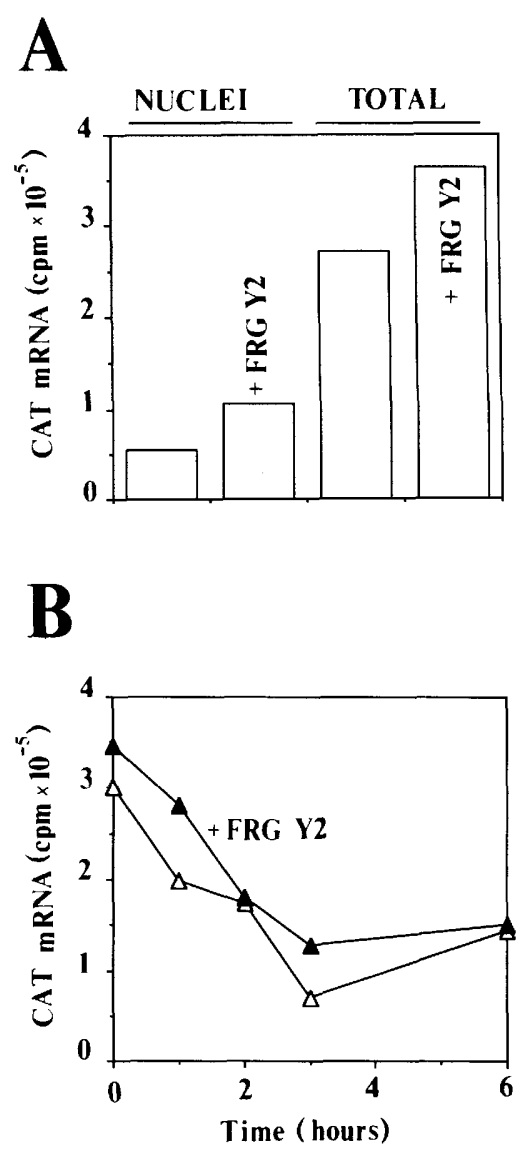

Figure 6. Nuclear accumulation and overall stability of CAT mRNA in the presence of FRGY2. (A) Nuclear CAT mRNA. Cells were cotransfected with HSP-CAT $(2 \mu \mathrm{g})$ and either the CMV expression vector $(2 \mu \mathrm{g})$ or the CMVY2 construct $(2 \mu \mathrm{g})$. After $10 \mathrm{hr}$, equivalent batches of cells were used directly for isolation of CAT mRNA or nuclei were isolated before CAT mRNA levels were assayed (Materials and methods). (B) Stability of CAT mRNA. Cells were transfected with HSP-CAT alone $(4 \mu \mathrm{g})$ or with HSP-CAT $(2 \mu \mathrm{g})$ plus CMVY2 $(2 \mu \mathrm{g})$. Thirty hours after transfection, the cells were treated with actinomycin $D$ to inhibit further transcription $(5 \mu \mathrm{g} / \mathrm{ml})$. CAT mRNA levels were then assayed at various times as indicated.

mulation of CAT mRNA in response to FRGY2 expression is attributable to molecular mechanisms operating within the nucleus. The increased accumulation of CAT mRNA in the nucleus could be the result of increased transcription from a Y-box-containing promoter (Tafuri and Wolffe 1990, 1992) or a Y-box-specific influence on nuclear export of mRNA. However, de la Pena and Zasloff (1987) noted that the TATA box, but not the Y box of the HSV tk promoter, influenced the export of tk mRNA from the nuclei of Xenopus oocytes. Likewise, we have not found the $\mathrm{Y}$ boxes of the Xenopus hsp70 promoter to influence the export of CAT mRNA in Xenopus oocytes (M. Ranjan and A.P. Wolffe, in prep.). The simplest interpretation is that FRGY2 directly facilitates increased transcription from the Xenopus hsp70 and 
HSV tK promoter containing $\mathrm{Y}$ boxes (Tafuri and Wolffe 1990, 1992).

\section{The DNA-binding domain of FRGY2 influences transcription and translation}

We have previously defined domains of the Xenopus Y-box proteins that are required both for interaction with DNA and transcriptional stimulation in vitro (Tafuri and Wolffe 1992). A region of $\sim 80$ amino acids (30-111 in FRGY2) is highly conserved in FRGY2, FRGY1, and in the prokaryotic cold shock proteins (Tafuri and Wolffe 1990; Wistow 1990). This cold shock domain $(C S D)$ is absolutely required for sequence-selective DNA binding to the core of the Y box (ATTGG) and for transcriptional stimulation (Tafuri and Wolffe 1992). The eukaryotic Y-box proteins contain a second Tail domain at the carboxyl terminus (111-337 in FRGY2) consisting of alternating blocks ( 30 amino acids each) of acidic or basic amino acids. This Tail domain does not bind DNA in isolation but facilitates DNA binding and protein-protein interactions between the intact Y-box proteins (Tafuri and Wolffe 1992). We have found that both the CSD and Tail domain contribute to RNA binding, and mutations in the CSD will still allow the protein to interact with RNA (S.R. Tafuri and A.P. Wolffe, in prep.).

We wished to explore whether the CSD, which is responsible for sequence selective interaction with DNA, would possess any of the activities of the intact FRGY2 protein in somatic cells. As a control, we examined the effects of expressing the Tail domain without the CSD in somatic cells. The modified FRGY2 proteins encoded by the truncated cDNAs fused to the CMV promoter are shown in Figure 7A. The accumulation of protein with increasing amounts of transfected expression vector is shown in Figure 7C. It should be noted that the Tail domain shows anomalous electrophoretic mobility, probably owing to a highly elongated shape (Deschamps et al. 1992). The influence of expression of these proteins on the accumulation of CAT mRNA, whose synthesis was directed by the $h s p 70$ promoter with the $\mathrm{Y}$ boxes intact, is shown in Figure $7 \mathrm{~B}$ and quantitated in Figure 9A, below. The FRGY2 protein and the CSD protein direct increases in the accumulation of CAT mRNA, whereas the Tail domain is without effect. This is consistent with a role for the DNA-binding domain of the Y-box proteins in transcriptional activation (Tafuri and Wolffe 1992).

We then examined the localization of the CSD and the carboxy-terminal Tail domain in A6 cells. We find that the CSD shows a predominantly cytoplasmic localization similar to the intact FRGY2 protein, whereas the Tail domain is predominantly in the nucleus, with strong staining in the nucleolus (Fig. 8). Thus, the CSD behaves like the intact protein FRGY2, in having a predominant localization to the cytoplasm. This localization is not attributable simply to interaction with RNA, because the Tail domain will also bind RNA. We suggest
A
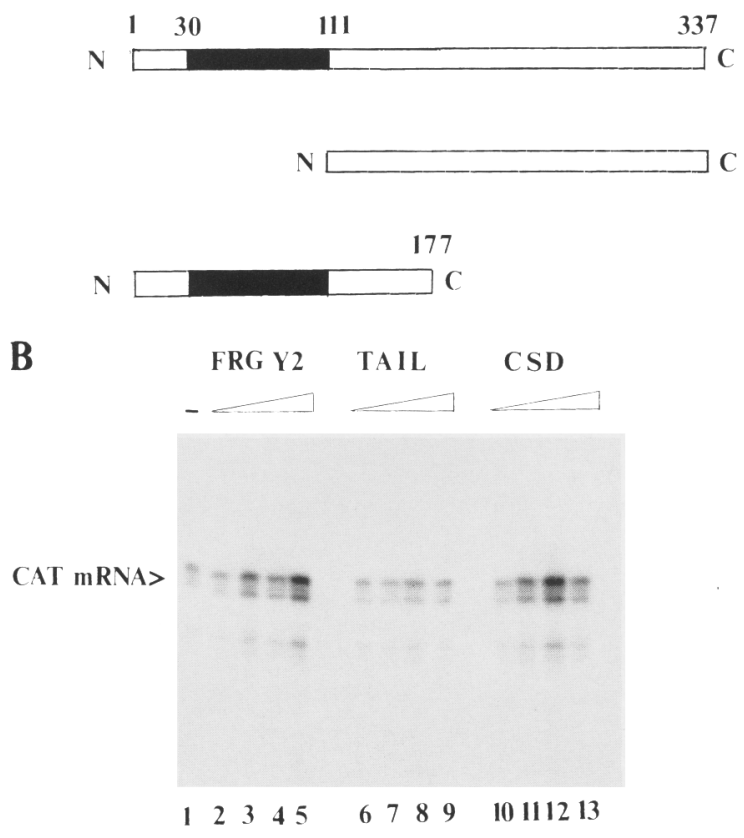

C

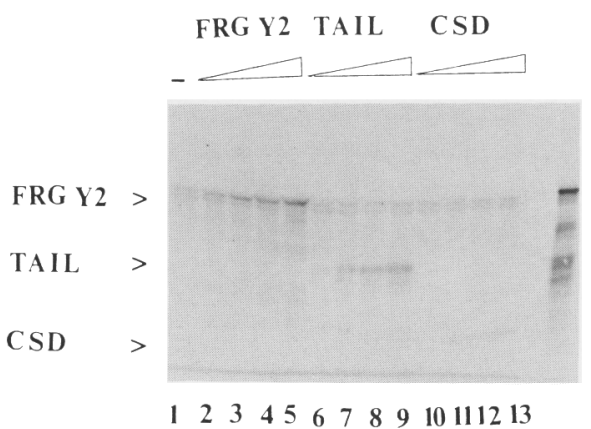

Figure 7. Transcriptional activation by FRGY2 deletion mutants. $(A)$ Schematic of FRG Y2 deletion mutants. The solid rectangle represents the essential DNA-binding domain. $(B)$ RNA from cells transfected with just $1 \mu \mathrm{g}$ of HSP-CAT (lane 1) or cotransfected with $1 \mu \mathrm{g}$ of HSP-CAT and $0.1,0.5,1$, and $2 \mu \mathrm{g}$ of CMV Y2 (lanes 2-5), CMV Y2.Tail (lanes 6-9), or CMV Y2.CSD (lanes 10-13) analyzed by RNase protection as in Fig. 2. (C) Immunoblot (with antibodies against FRGY2) of cells transfected in parallel to those used for RNase protection in $B$.

that the CSD must interact with a cytoplasmic structure to affect its localization (see Discussion).

We then examined whether the accumulation of either of the truncated proteins would influence the translation process, as both the CSD and the Tail domain will interact with RNA. We find that both truncated proteins inhibit CAT mRNA translation equivalently to the fulllength FRGY2 protein (Fig. 9B). Because the Tail domain will not interact specifically with DNA (Tafuri and Wolffe 1992), there is no need for a prior interaction of the Y-box protein or derivatives with the Y-box DNA 


\section{CSD}

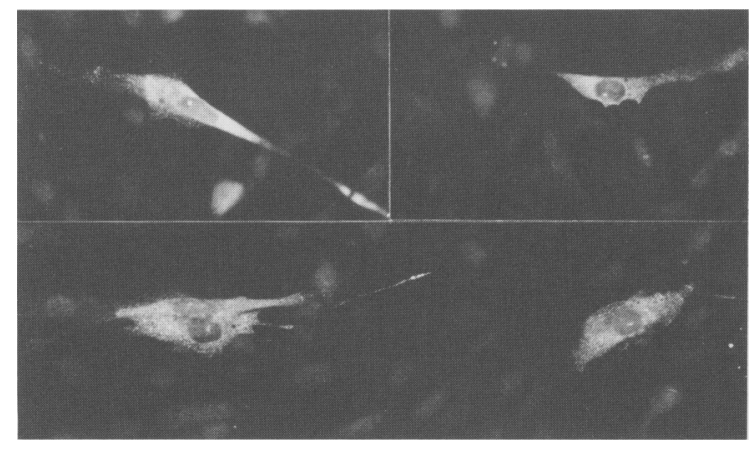

\section{TAIL}

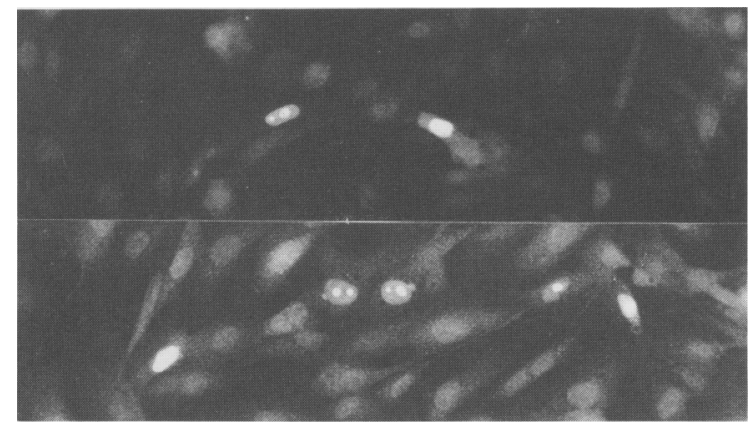

Figure 8. Localization of FRGY2 deletion mutants. Immunostaining with antibodies against FRGY2 of A6 cells transfected with $2 \mu \mathrm{g}$ of CMV Y2.CSD (top) or $2 \mu \mathrm{g}$ of CMV Y2.Tail (bottom).

sequence elements to cause the translational repression of CAT mRNA. Thus, the transcriptional stimulation of the hsp 70 promoter that is dependent on the Y-box elements can be separated from the apparently nonspecific repression of translation mediated by the Y-box proteins. The inhibition of translation by the CSD and the Tail domain could be the result of independent interactions of either domain with mRNA or the overlap region between the two proteins. Future experiments will explore these possibilities.

\section{Discussion}

We have explored the in vivo role of the oocyte-specific Y-box protein FRGY2 in activating transcription from promoters containing binding sites for the protein and in regulating the translation of mRNAs whose synthesis is directed from such promoters. Surprisingly, we have found the FRGY2 protein to have a dual role, both directing the accumulation of mRNA from Y-box-containing promoters and repressing the translation of the accumulated mRNA. These effects are consistent with the proposed in vivo roles for the FRGY2 protein, which are that it activates transcription from promoters containing the Y-box sequence element (Tafuri and Wolffe 1990) and sequesters maternal mRNA from translation (Sommerville 1990). The proposed role of the FRGY2 protein in maternal mRNA transcription and storage resembles that of the transcription factor TFIIIA. TFIIIA activates transcription of the oocyte-type 5S rRNA genes and sequesters the transcribed 5S rRNA in the cytoplasm (Pelham and Brown 1980; Wolffe and Brown 1988).

\section{A role for FRGY2 in transcription}

Our in vivo results (Figs. 2, 6, and 7) suggest that FRGY2 activates transcription from two promoters containing Y-box elements: the $h s p 70$ promoter and the HSV tk promoter. Mutation of the $\mathrm{Y}$ boxes within the hsp 70 promoter abolishes the response (Fig. 2). A comparable activation of transcription is observed when the DNAbinding domain of the FRGY2 protein is transfected into somatic cells (Fig. 7). This suggests that the protein is functioning at the promoter through DNA binding alone (Tafuri and Wolffe 1992). However, we cannot formally exclude the possibility that the levels of CAT mRNA increase as a consequence of an inhibition of nuclear export in a promoter-dependent manner (see, e.g., de la Pena and Zasloff 1987).

Our interpretations are complicated by the presence of endogenous FRGY1 in the nuclei of A6 cells (Figs. 1). FRGY1 or other proteins capable of interacting with Y-box sequence elements (NF-Y (Dorn et al. 1987) or other CCAAT homology-binding proteins (Faisst and Meyer 1992)] might also contribute to transcriptional activation from the HSV tk and $h s p 70$ promoters in the absence of FRGY2. This might also account for the relatively low three- to fivefold increase in CAT mRNA accumulation in the presence of FRGY2. It is also conceivable that FRGY2 or the CSD might influence the distribution of other activators in the cell (including FRGYI) by titrating out less specific binding sites for Y-box-binding proteins. However, these reservations extend to the interpretation of all transient expression assays employing cotransfection of activator and reporter constructs.

Y-box elements are associated with promoters that are highly active in Xenopus oocytes (Bienz 1986; Graves et al. 1986; Toyoda and Wolffe 1992; Wolffe et al. 1992). Previously, we have found the FRGY2 protein to reconstitute transcription from the Xenopus $h s p 70$ promoter using Xenopus in vitro transcription extracts functionally depleted of Y-box proteins (Tafuri and Wolffe 1990). Reconstitution of the in vitro transcription extract with truncated forms of FRGY2 demonstrated that the protein did not contain separate activating and DNA-binding domains but facilitated transcription through DNA binding alone (Tafuri and Wolffe 1992). The FRGY2 protein may function like the bacterial histone-like proteins in their interaction with DNA to alter promoter conformation to facilitate transcription. The DNA-binding properties of the bacterial cold shock proteins suggest a comparable role for these proteins (La Teana et al. 1991; Jones et al. 1992; Wolffe et al. 1992). The identity between the eukaryotic and prokaryotic proteins suggests 
A

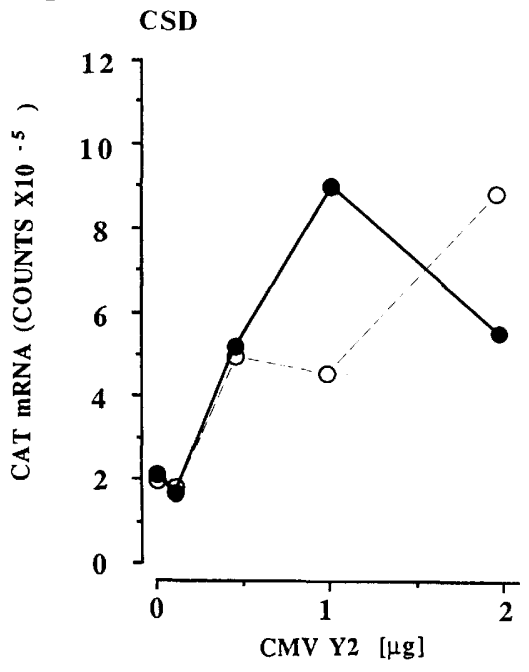

B

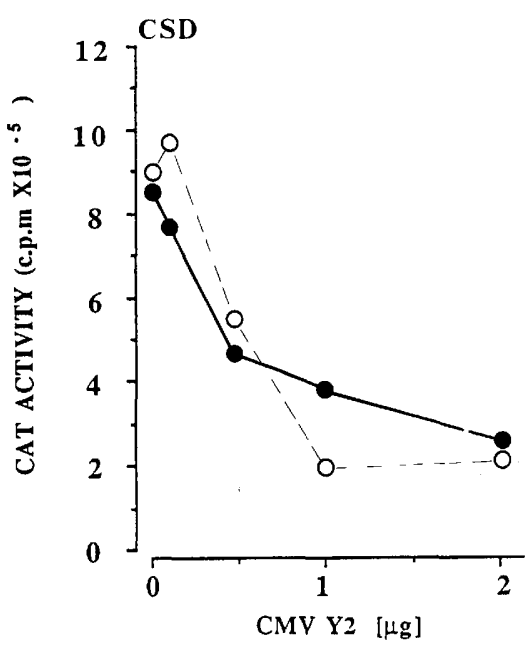

TAIL
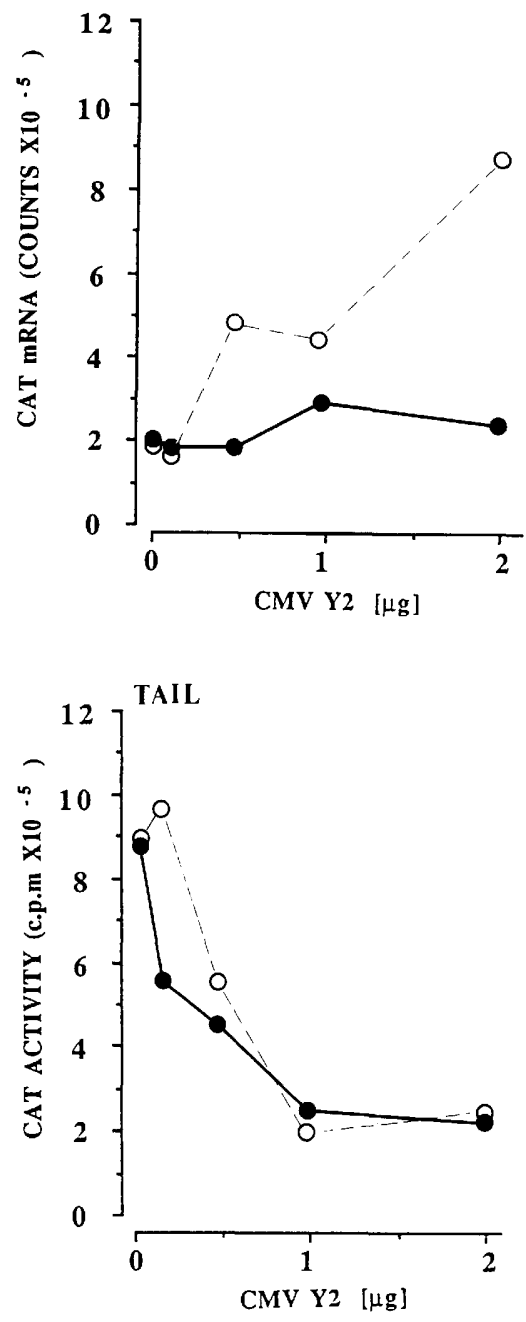

Figure 9. Transcriptional activation and translational repression by FRGY2 deletion mutants. $(A)$ CAT mRNA accumulation in response to expression of the CSD or Tail domain of FRGY2. (Left) CSD. CAT mRNA levels are shown from cells transfected with $1 \mu \mathrm{g}$ of HSP-CAT plus, 0, 0.1, $0.5,1$, and $2 \mu \mathrm{g}$ of either CMV.Y2 $(O)$ or CMV Y2.CSD (). (Right) Tail. CAT mRNA levels are shown from cells transfected with $1 \mu \mathrm{g}$ of HSP-CAT plus 0, 0.1, $0.5,1$, and $2 \mu \mathrm{g}$ of either CMV.Y2 (O) or CMV Y2.Tail (O). (B) CAT activity in response to expression of the CSD or Tail domain of FRGY2. (Left) CAT activities are shown from cells transfected with $1 \mu \mathrm{g}$ of HSP-CAT plus $0,0.1,0.5,1$, and $2 \mu \mathrm{g}$ of either CMV.Y2 (O) or CMV Y2.CSD (O). (Right) CAT activities are shown from cells transfected with $1 \mu \mathrm{g}$ of HSP-CAT plus $0,0.1,0.5,1$, and $2 \mu \mathrm{g}$ of CMV.Y2 $(O)$ or CMV Y2.Tail (@). that the proteins originally evolved with the capacity to bind to DNA. It is not known whether the prokaryotic cold shock proteins interact with RNA. It is possible that the FRGY2 protein might also influence transcription initiation through mechanisms analogous to those proposed for the Tat regulator of the HIV-1 LTR. Tat is a trans-activator of HIV-1 gene expression that has been proposed to interact with the nascent transcript containing a defined RNA structure (TAR) and to communicate with the basal RNA polymerase II transcriptional machinery. Evidence also exists for activation of transcription by Tat that is dependent on specific regions of the promoter (Berkhout et al. 1990). In any event, it represents an example of an RNA-binding protein that activates transcription through cis-acting sequences.

The proteins FRGY2 and the CSD that stimulate the accumulation of CAT mRNA are found predominantly in the cytoplasm of the A6 cell. Nuclear staining with FRGY2 and the CSD is also apparent (Figs. 1 and 8). This type of staining does not exclude a role for FRGY2 and the CSD in transcriptional stimulation, because TFIIIA is well known to activate 5S RNA gene transcription but accumulates predominantly in the cytoplasm of oocytes (Mattaj et al. 1983). Association of TFIIIA with 5S RNA is necessary for the export of TFIIIA to the cytoplasm (Guddat et al. 1990). The cytoplasmic localization of FRGY2 is strongly dependent on the CSD because removal of this domain results in nuclear localization of the expressed Tail domain protein (Fig. 8). This also shows that the Tail domain does contain nuclear localization signals; these must be masked or overcome by the CSD. For example, the FRGY2 CSD might be able to obscure the nuclear localization signal in the Tail domain by protein folding. However, addition of an extra SV40 nuclear localization signal (PKKKRKV) at the amino terminus of FRGY2 also fails to cause nuclear localization (M. Ranjan, unpubl.). The capacity to associate with RNA alone cannot determine nuclear or cytoplasmic localization, as the Tail domain of FRGY2 can bind RNA, yet remains in the nucleus and accumulates 
in the nucleolus. Cytoplasmic localization may be the result of the association of the CSD with cytoplasmic structures. These may be important for the sequestration of maternal mRNAs in particular regions of the oocyte cytoplasm (Schwartz et al. 1992). It should be noted that several trans-acting factors, including NF- $\mathrm{KB}$ and the glucocorticoid receptor, have a predominantly cytoplasmic localization in the absence of the correct transcriptional inducer (Picard and Yamamoto 1987; Baeuerle and Baltimore 1988). We will attempt to delineate the precise determinants and mechanism of the cellular compartmentalization of FRGY2 in further experiments.

\section{FRGY2 masks mRNA from translation}

Accumulation of FRGY2 protein or truncated derivatives in somatic cells leads to the repression of translation of CAT mRNA (Figs. 3, 4, and 9). Although this translational effect is specific to the expression of FRGY2 (Fig. 4), the translation of all mRNAs examined is repressed, including those from promoters not containing Y-box elements (Fig. 3; data not shown). DNA binding is not required for translational repression, because the Tail domain of the Y-box proteins, which will not interact specifically with DNA or activate transcription (Tafuri and Wolffe 1992), also represses translation as effectively as the intact protein. Thus, transcriptional stimulation and translational repression by the Y-box proteins can be separated into distinct phenomena.

How does translational repression occur? The intact Y-box protein does not destabilize CAT mRNA (Fig. 6B) nor does it cause the irreversible retention of the CAT mRNA in the nucleus (Fig. 6A), although it may influence the efficiency of nuclear export. Both the CSD and Tail domain interact with RNA and repress translation yet localize in distinct regions of the cell. The CSD, like the intact protein, accumulates in the cytoplasm, whereas the Tail domain accumulates in the nucleolus. Thus, the predominant subcellular localization of the proteins is not important for the repressive effect on translation. It is generally thought that distinct sets of proteins bind to mRNA in the nucleus and in the cytoplasm (for review, see Dreyfuss 1986; Dreyfuss et al. 1988 |, although recent evidence suggests that this is not always the case (Piñol-Roma and Dreyfuss 1992). The Tail domain of the Y-box proteins has similarities to molecular chaperones, such as Nopp140, that are believed to shuttle between the nucleolus and the cytoplasm. Both proteins contain large regions of alternating blocks of acidic and basic amino acids (Meier and Blobel 1992). This type of domain has been suggested as a binding site for nucleoprotein complexes (preribosomal complexes for Nopp140). We suggest that the Tail domain, together with the CSD in FRGY2, might interact with the complexes of mRNA and associated translational regulatory proteins in the oocyte and interfere either with the normal processing of this mRNA in the nucleus and/or its subsequent assembly onto ribosomes in the cytoplasm. Our results also demonstrate that although association of the Y-box proteins with mRNA in vivo inhibits translation (like in vitro, Richter and Smith 1984), this inhibition does not prevent subsequent degradation of the associated mRNA in somatic cells. Thus, the Y-box proteins do not necessarily function to render the mRNA inert and not accessible to RNA-binding proteins, such as RNases. Rather, they may function to package and compact mRNA in a way that retains accessibility to RNA-binding proteins, as the histones package eukaryotic DNA in a manner accessible to regulatory factors and polymerases.

\section{Materials and methods \\ Cell culture and transfections}

A6 cells obtained from ATCC (Rockville MD) were grown in $67 \%$ Leibovitz L15 medium supplemented with $10 \%$ fetal calf serum (GIBCO-BRL). The cells were cultured at $22^{\circ} \mathrm{C}$ under air. Cells plated at $1.2 \times 10^{6}$ in $25-\mathrm{cm}^{2}$ flasks were transfected the following day after reaching $90 \%$ confluence. These were washed twice with serum-free media before addition of a mixture of $40 \mu \mathrm{l}$ of lipofectin (GIBCO-BRL) and DNA to each flask according to the manufacturer's instructions. All DNA amounts were equalized using expression vector without any insert. After incubation for $24 \mathrm{hr}$ at $22^{\circ} \mathrm{C}$, transfection was stopped by addition of serum, and the cells were incubated for another $48 \mathrm{hr}$ in the presence of serum.

\section{CAT assays}

Cell extracts for CAT assays were prepared by three cycles of freeze/thawing in $100 \mu 1$ of $0.25 \mathrm{M}$ Tris (pH 7.8), and the supernatant was used for assays. The CAT assays themselves were performed using a modified protocol as described by Nordeen et al. (1987). Briefly, the assay utilizes acetyl CoA synthase that catalyzes the continuous production of labeled acetyl CoA from ${ }^{3} \mathrm{H}$-labeled acetate and CoA. This labeled acetyl CoA and unlabeled chloramphenicol are then used as substrate by the CAT enzyme in the same reaction. After a 2 -hr incubation at $37^{\circ} \mathrm{C}$, the labeled chloramphenicol (acetylated) is extracted with benzene and quantitated directly by liquid scintillation counting. Data were normalized to protein concentrations. All data are from at least three experiments with two replicates for each experimental condition.

\section{Western blots}

Cell extracts prepared using a triple detergent buffer (Sambrook et al. 1989/ were run on $10 \%$ SDS gels and electroblotted at a constant voltage of $30 \mathrm{~V}$ onto nitrocellulose. The FRGY2 protein passed through the first two nitrocellulose filters, and we used the third filter to probe with antibodies. The greater mobility of the FRGY2 proteins also helped to establish identity, as the other cross-reacting bands were retained on the first filter. A $1: 400$ concentration of the primary antibody [raised in rabbits against gel-purified bacterially expressed FRGY protein (Tafuri and Wolffe 1992)] was used, whereas the second antibody (antirabbit AP; Promega Corp.) was used at the recommended concentration of $1: 7500$. The blot was developed using a nitro blue tetrazolium/5-bromo-4-chloro-3-indolyl phosphate assay (Promega) for alkaline phosphatase activity.

\section{Immunofluorescence}

Cells grown on Lab-Tek (Nunc) glass slides were fixed with $2 \%$ formalin for $5 \mathrm{~min}$ at room temperature and stained with pri- 
mary antibody at $1: 200$ (30 min), followed by secondary antibody (rhodamine-conjugated goat anti-rabbit IgG; Boehringer) at $1: 200(20 \mathrm{~min})$. The cells were then mounted in $90 \%$ glycerol and viewed using a rhodamine filter.

\section{Nuclear fractionation}

Nuclei were prepared from A6 cells as described previously (Toyoda and Wolffe 1992). The washed cells were suspended in $4 \mathrm{ml} / \mathrm{gram}$ of cells in buffer A $10.35 \mathrm{M}$ sucrose, $15 \mathrm{~mm}$ HEPES$\mathrm{KOH}$ at $\mathrm{pH} 7.6,10 \mathrm{mM} \mathrm{KCl}, 5 \mathrm{mM} \mathrm{MgCl}_{2}, 0.1 \mathrm{~mm}$ EDTA, 0.5 mM EGTA, $1 \mathrm{mM}$ DTT, $1 \mathrm{mM}$ PMSF, $1 \mu \mathrm{g} / \mathrm{ml}$ of leupeptin, $0.1 \%$ Triton X-100) and were homogenized in a Dounce homogenizer with a B pestle $(6-10$ strokes). The homogenate was passed through three layers of cheesecloth to eliminate intact cells and then centrifuged at $4000 \mathrm{rpm}$ in a Sorvall SS-34 rotor for $10 \mathrm{~min}$ (1900G). Nuclear pellets were resuspended gently in buffer A (2 $\mathrm{ml} / \mathrm{gram}$ of cells), and the nuclei were layered in $6-\mathrm{ml}$ aliquots over an equal volume of buffer $B$ \{0.8 $\mathrm{M}$ sucrose, $15 \mathrm{mM}$ HEPES$\mathrm{KOH}$ at $\mathrm{pH} 7.6,10 \mathrm{mM} \mathrm{KCl}, 5 \mathrm{~mm} \mathrm{MgCl}_{2}, 0.1 \mathrm{~mm}$ EDTA, 0.5 mM EGTA, $1 \mathrm{mM}$ PMSF, $10 \mu \mathrm{g} / \mathrm{ml}$ of leupeptin) in $15-\mathrm{ml}$ graduated polycarbonate tubes. Nuclei were pelleted by centrifugation in a Sorvall HB-4 rotor at $5000 \mathrm{rpm}$ for $10 \mathrm{~min}$ (4000g).

\section{mRNP fractionation}

A6 cells ( 0.2 grams) were homogenized in $200 \mu$ l of $1 \times$ gradient buffer $\left(0.3 \mathrm{M} \mathrm{KCl}, 2 \mathrm{mM} \mathrm{MgCl}_{2}, 20 \mathrm{~mm}\right.$ HEPES at $\mathrm{pH} 7.4,0.1 \%$ diethylpyrocarbonate, $0.5 \% \mathrm{NP}-40$ ) and centrifuged in a microcentrifuge at maximum speed $(12,000 \mathrm{~g})$ for $10 \mathrm{~min}$ at $4^{\circ} \mathrm{C}$. Twenty units of RNasin was added to the clarified supernatant, and this homogenate was loaded onto a $1.5-\mathrm{ml} 20-60 \%$ Nycodenz gradient (Accurate Chemical and Scientific Corp.). The gradient was centrifuged at $150,000 \mathrm{~g}$ for $20 \mathrm{hr}$ in a TLS-55 rotor. After centrifugation, the gradient was fractionated into twenty 75- $\mu \mathrm{l}$ fractions. Fifteen microliters of each fraction was dialyzed against phosphate buffer $\left(50 \mathrm{mM} \mathrm{NaH} \mathrm{PO}_{4} / \mathrm{Na}_{2} \mathrm{HPO}_{4}\right.$ at $\mathrm{pH} 7.2$, $5 \mathrm{~mm}$ EDTA, $5 \mathrm{~mm}$ EGTA, $1 \mathrm{~mm} \mathrm{DTT}, 100 \mathrm{~mm} \mathrm{NaCl}$ / to remove the Nycodenz before SDS-PAGE. Western blot analysis was performed using the rabbit polyclonal antibody TAF3, which was prepared against the bacterial FRGY2 protein.

\section{RNA extraction and analysis}

Total RNA extracted from transfected cells using RNAzol (Cinna/Biotecx) was analyzed by RNase protection assay. Reagents obtained from Ambion, Inc., were used for the assay and generation of riboprobes according to the manufacturer's instructions. A 673-bp ScaI-XhoI CAT fragment from pBLCAT2 (Luckow and Schultz 1987) was cloned into EcoRV-XhoI-cut pBS SK $(-)$ (Stratagene). The resulting plasmid pBSCAT was linearized with $\mathrm{NcoI}$ and transcribed by T3 polymerase to make an antisense probe to CAT mRNA that protects a 117-bp fragment. Twenty micrograms of total RNA was hybridized with CAT riboprobe at $42^{\circ} \mathrm{C}$ and then digested with RNase A/T1 $(1: 300$ dilution). Samples were analyzed on an $8 \mathrm{M}$ urea $/ 6 \%$ acrylamide gel. Protected fragments were visualized and quantitated using a Molecular Dynamics Series 400 PhosphorImager and ImageQuant version 3.2 software.

\section{Plasmids}

The expression vector pCMV3.1 was constructed by replacing the multiple cloning site (MCS) in pCMV3 with a synthetic MCS formed by hybridizing two oligonucleotides: 5 '-AGCTTCTAG AGCGGCCGCGGATATCAGATCTC-3' and 5'-CT-
AGGAGATCTGATATCCGCGGCCGCT CTAGA-3'. pCMV3 was created by removing the HindIII-XbaI fragment containing the IL-2 from pCMVIL2R (Giordano et al. 1991) and replacing it with a HindIII-XbaI fragment from pcDNA I (Invitrogen) containing its multiple cloning site. Full-length FRGY2 cDNA was then cloned into the $X b a \mathrm{I}-E c o R V$ site of pCMV3.1. A 343-bp fragment containing the Xenopus hsp 70 promoter $(-256$ to +88 ) was generated by PCR from the plasmid pXL10XP (Bienz 1984) and cloned into the XbaI-HindIII site of pCAT Basic (Promega). To generate the Y-box mutant HSP-CAT, CCAAT1 and CCAAT2 were changed to CGGCC and TACTC, respectively, by PCR. pBLCAT2 (Luckow and Schultz 1987) containing a BamHI-BgIII fragment from the linker-scanning mutant LS-115/-105 (McKnight and Kingsbury 1982) was used as tk CAT. The tk CAT mutant $\mathrm{Y}$ box was generated by converting the CCAAT site to CAGGT using PCR. FRGY2 CSD was made by converting amino acid 178 of FRGY2 (tyrosine, UAC) to a stop codon (UAA) by PCR. The FRGY2 tail was made by inserting the FRGY2 translation start sequence (AAG AGC ATG) in front of amino acid 109 (threonine), which is at the carboxyterminal end of the CSD.

\section{References}

Av-Gay, Y., Y. Aharonowitz, and G. Cohen. 1992. Steptomyces contain a 7.0KDa cold shock like protein. Nucleic Acids Res. 20: 5478 .

Baeuerle, P.A. and D. Baltimore. 1988. Activation of DNA-binding activity in an apparently cytoplasmic precursor of the NF-кB transcription factor. Cell 53: 211-217.

Berkhout, B., A. Gatignol, A.B. Rabson, and K.T. Jeang. 1990. TAR-independent activation of the HIV-1 LTR: Evidence that Tat requires specific regions of the promoter. Cell 62: 757-767.

Bienz, M. 1984. Xenopus hsp70 genes are constitutively expressed in injected oocytes. EMBO J. 3: 2477-2483.

1986. A CCAAT box confers cell-type-specific regulation of the Xenopus hsp70 gene in oocytes. Cell 46: 10371042.

Crawford, D.R. and J.D. Richter. 1987. An RNA-binding protein from Xenopus oocytes is associated with specific message sequences. Development 101: 741-749.

Darnbrough, D.H. and P.J. Ford. 1981. Identification in Xenopus laevis of a class of oocyte specific proteins bound to messenger RNA. Eur. I. Biochem. 113: 415-424.

Deschamps, S., A. Viel, M. Garrigos, H. Denis, and M. le Maire. 1992. mRNP4, a major mRNA-binding protein from Xenopus oocytes is identical to transcription factor FRGY2. I. Biol. Chem. 267: 13799-13802.

Didier, D.K., J. Schiffenbauer, S.L. Woulfe, M. Zaceis, and B.D. Schwartz. 1988. Characterization of the cDNA encoding a protein binding to the major histocompatibility complex class II Y box. Proc. Natl. Acad. Sci. 85: 283-287.

Dorn, A., J. Bollekens, A. Staub, C. Benoist, and D. Mathis. 1987b. A multiplicity of CCAAT-box binding proteins. Cell 50: $863-872$.

Dreyfuss, G. 1986. Structure and function of nuclear and cytoplasmic ribonucleoprotein particles. Annu. Rev. Cell Biol. 2: $459-498$.

Dreyfuss, G., M.S. Swanson, and S. Piñol-Roma. 1988. Heterogeneous nuclear ribonucleoprotein particles and the pathway of mRNA formation. Trends Biochem. Sci. 13: 86-91.

Engelke, D.R., S.-Y. Ng, B.S. Shastry, and R.G. Roeder. 1980. Specific interaction of a purified transcription factor with an internal control region of 5S RNA genes. Cell 19: 717-728. 
Faisst, S. and S. Meyer. 1992. Compilation of vertebrate-encoded transcription factors. Nucleic Acids Res. 20: 3-26.

Ghazal, P., H. Lubon, and L. Hennighausen. 1988. Multiple sequence specific transcription factor modulate cytomegalovirus enhancer activity in vitro. Mol. Cell. Biol. 8: 1809-1811.

Giordano, T., T.H. Howard, J. Coleman, K. Sakamoto, and B.H. Howard. 1991. Isolation of a population of transiently transfected quiescent and senescent cells by magnetic affinity cell sorting. Exp. Cell Res. 192: 193-197.

Goldstein, J., N.S. Pollitt, and M. Inouye. 1990. Major cold shock protein of Escherichia coli. Proc. Natl. Acad. Sci. 87: 283-287.

Graves, B.J., P.F. Johnson, and S.L. McKnight. 1986. Homologous recognition of a promoter domain common to the MSV LTR and the HSV tk gene. Cell 44: 565-576.

Guddat, U., A.H. Bakken, and T. Pieler. 1990. Protein mediated nuclear export of RNA: 5S rRNA containing small RNPs in Xenopus oocytes. Cell 60: 619-628.

Jones, P., R. Krah, S.R. Tafuri, and A.P. Wolffe. 1992. DNA gyrase, CS7.4 and the cold shock response in Escherichia coli. J. Bacteriol. 174: 5798-5802.

Kolluri, R., T.A. Torrey, and A.J. Kinniburgh. 1992. A CT promoter element binding protein: Definition of a doublestrand and a novel single-strand DNA binding motif. $\mathrm{Nu}$ cleic Acids Res. 20: 111-116.

La Teana, A., A. Bandi, M. Falconi, R. Sprino, C.L. Pon, and C.O. Gualerzi. 1991. Identification of a cold shock transcriptional enhancer of the Escherichia coli gene encoding nucleoid protein H-NS. Proc. Natl. Acad. Sci. 88: 10907-10911.

Lauret, E. and R. Baserga. 1988. Inhibition of gene expression at the translational level by cotransfection with competitor plasmids. DNA 7: 151-156.

Luckow, B. and G. Schultz. 1987. Cat constructions with multiple unique restriction sites for the functional analysis of eukaryotic promotors and regulatory elements. Nucleic Acids Res. 15: 4590.

Mattaj, I.W., S. Lienhard, R. Zeller, and E.M. De Robertis. 1983. Nuclear exclusion of transcription factor IIIA and the $42 \mathrm{~S}$ particle transfer RNA-binding protein in Xenopus laevis oocytes: A possible mechanism for gene control. J. Cell Biol. 97: 1261-1265.

McKnight, S.L. and R. Kingsbury. 1982. Transcriptional control signals of a eukaryotic protein coding gene. Science 217: $316-324$

Meier, U.T. and G. Blobel. 1992. Nopp140 shuttles on tracks between the nucleolus and cytoplasm. Cell 70: 128-138.

Murray, M.T., D.L. Schiller, and W.W. Franke. 1992. Sequence analysis of cytoplasmic mRNA-binding proteins of Xenopus oocytes identifies a family of RNA-binding proteins. Proc. Natl. Acad. Sci. 89: 11-15.

Nordeen, S.K., P.P. Green III, and D.M. Fowlkes. 1987. A rapid sensitive and inexpensive assay for chloramphenicol acetyl transferase. DNA 6: 173-178.

Pelham, H.R.B. and D.D. Brown. 1980. A specific transcription factor can bind either the 5S RNA gene or 5S RNA. Proc. Natl. Acad. Sci. 77: 4170-4174.

Picard, D. and K.R. Yamamoto. 1987. Two signals mediate hormone dependent nuclear localization of the glucocorticoid receptor. EMBO 1. 6: 3333-3340.

Piñol-Roma, S. and G. Dreyfuss. 1992. Shuttling of pre-mRNA binding proteins between nucleus and cytoplasm. Nature 355: 730-732.

Richter, J.D. 1988. Information relay from gene to protein: The mRNP connection. Trends Biochem. Sci. 13: 483-486.

. 1991. Translational control during early development. BioEssays 13: 179-183.
Richter, J.D. and L.D. Smith. 1983. Developmentally regulated RNA-binding proteins during oogenesis in Xenopus laevis. I. Biol. Chem. 258: 4864-4872.

- 1984. Reversible inhibition of translation by Xenopus oocyte specific proteins. Nature 309: 378-380.

Sambrook, J., E.F. Fritsch, and T. Maniatis. 1989. Molecular cloning: A laboratory manual, 2nd ed. Cold Spring Harbor Laboratory Press, Cold Spring Harbor, New York.

Schwartz, S.P., L. Aisenthal, Z. Elisha, F. Oberman, and J.K. Yisraeli. 1992. A 69KDa RNA-binding protein from Xenopus oocytes recognizes a common motif in two vegetally localized maternal mRNAs. Proc. Natl. Acad. Sci. 89: 1189511899.

Sommerville, J. 1990. RNA binding phosphoproteins and the regulation of maternal mRNA in Xenopus. J. Reprod. Fertil. (Suppl.) 42: 225-233.

Spirin, A.S. 1966. On "masked" forms of messenger RNA in early embrogenesis and in other differentiating systems. Curr. Top. Dev. Biol. 1: 1-63.

1969. Informosomes. Eur. I. Biochem. 10: 20-35.

Tafuri, S.R. and A.P. Wolffe. 1990. Xenopus Y-box transcription factors: Molecular cloning, functional analysis and developmental regulation. Proc. Natl. Acad. Sci. 87: 9028-9032.

1992. DNA binding, multimerization and transcription stimulation by the Xenopus $\mathrm{Y}$ box proteins in vitro. New Biol. 4: 349-359.

Tafuri, S.R., M. Familari, and A.P. Wolffe. 1993. A mouse Y box protein, MSYl, is associated with paternal mRNA in spermatocytes. J. Biol. Chem. 268: 12213-12220.

Toyoda, T. and A.P. Wolffe. 1992. Characterization of RNA polymerase II dependent transcription in Xenopus extracts. Dev. Biol. 153: 150-157.

Wistow, G. 1990. Cold shock and DNA binding. Nature 344: 823-824.

Wolffe, A.P. and D.D. Brown. 1988. Developmental regulation of two 5S ribosomal RNA genes. Science 241: 1626-1632.

Wolffe, A.P., S. Tafuri, M. Ranjan, and M. Familari. 1992. The Y-box factors: A family of nucleic acid binding proteins conserved from Escherichia coli to man. New Biol. 4: 290-298. 


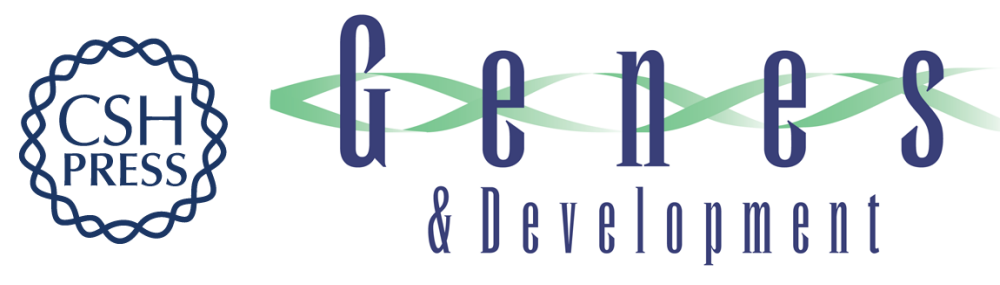

\section{Masking mRNA from translation in somatic cells.}

M Ranjan, S R Tafuri and A P Wolffe

Genes Dev. 1993, 7:

Access the most recent version at doi:10.1101/gad.7.9.1725 $\begin{array}{ll}\text { References } & \begin{array}{l}\text { This article cites } 47 \text { articles, } 15 \text { of which can be accessed free at: } \\ \text { http://genesdev.cshlp.org/content/7/9/1725.full.html\#ref-list-1 }\end{array}\end{array}$

License

Email Alerting Service

Receive free email alerts when new articles cite this article - sign up in the box at the top right corner of the article or click here.

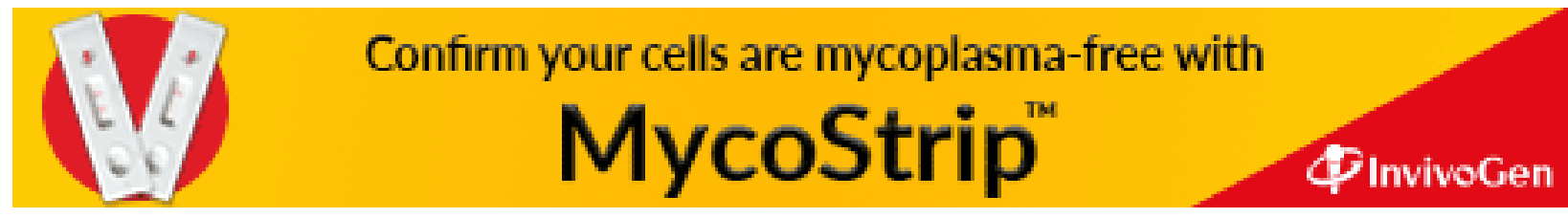

